\title{
Nutrient Uptake in Container-grown Impatiens and Petunia in Response to Root Substrate pH and Applied Micronutrient Concentration
}

\author{
Brandon R. Smith ${ }^{1}$ and Paul. R. Fisher ${ }^{2}$ \\ Department of Plant Biology, University of New Hampshire, Durham, NH 03824
}

William R. Argo

Blackmore Company, Belleville, MI 48111

Additional index words. iron, manganese, soilless medium, peat, chelate, ethylenedinitrilotetr aacetic acid, EDTA, SPAD, chlorophyll, carotenoid, fertilizer, greenhouse, floriculture

\begin{abstract}
The objective was to quantify the effect of substrate $\mathrm{pH}$ and micronutrient concentration on tissue nutrient levels in Petunia $\times$ hybrida Hort. Vilm.-Andr. and Impatiens wallerana Hook. F. Plants were grown in 10-cm-diameter pots for 4 weeks in a $70 \%$ peat : $30 \%$ perlite medium amended with five lime rates to achieve substrate $\mathrm{pH}$ values ranging from $\mathrm{pH} 4.4$ to 7.0. Plants were irrigated with (in $\mathrm{mg} \cdot \mathrm{L}^{-1}$ ) $210 \mathrm{~N}-31 \mathrm{P}-235 \mathrm{~K}-200 \mathrm{Ca}-49 \mathrm{Mg}$. Micronutrients were applied as an EDTA (ethylenedinitrilotetraacetic acid) chelated micronutrient blend (C111), at $1 \times, 2 \times$, and $4 \times$ concentrations of $0.50 \mathrm{Fe}-0.25 \mathrm{Mn}-0.025 \mathrm{Zn}-$ $0.04 \mathrm{Cu}-0.075 \mathrm{~B}-0.01 \mathrm{Mo}$. Patterns of tissue concentrations across substrate $\mathrm{pH}$ differed from nutrient solubility in the medium, particularly with regard to $\mathrm{Mn}$. Foliar $\mathrm{N}$ content decreased slightly as substrate $\mathrm{pH}$ increased, whereas foliar $\mathrm{Ca}, \mathrm{Mg}$, and $\mathrm{S}$ increased. Although foliar $\mathbf{P}$ and $\mathrm{K}$ varied with $\mathrm{pH}$, there was no consistent trend between species. Foliar total $\mathrm{Fe}$, ferrous $\mathrm{Fe}$, and $\mathrm{Cu}$ decreased as substrate $\mathrm{pH}$ increased, whereas foliar $\mathrm{Zn}$ increased. Foliar Mn content decreased for both species as $\mathrm{pH}$ rose to 6.0 , and then increased from pH 6.0 to 7.0. In contrast, Mn level in the substrate, measured in a saturated medium extract using deionized water as the extractant, decreased as $\mathbf{p H}$ increased from pH 4.4 to 7.0. Chlorophyll content decreased when the ratio of tissue Fe to Mn was

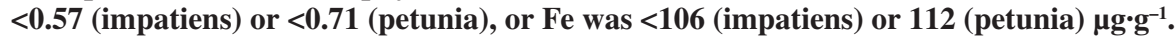
SPAD chlorophyll index also declined in petunia with foliar $\mathrm{Mn}>42 \mu \mathrm{g}^{-1} \mathrm{~g}^{-1}$. Increasing $\mathrm{C} 111$ increased foliar $\mathrm{Cu}$, total $\mathrm{Fe}$ and ferrous $\mathrm{Fe}$ in both species, and $\mathrm{B}$ for impatiens, and partly compensated for reduced nutrient solubility at high $\mathrm{pH}$.
\end{abstract}

Substrate $\mathrm{pH}$ affects nutrient solubility in a peat-based medium, and the resulting uptake of nutrients into plant tissue (Nelson, 1998; Peterson, 1981). Solubility of P, Fe, Mn, Zn, Cu, and $\mathrm{B}$ decrease as $\mathrm{pH}$ increases in a highly organic medium, whereas Mo solubility increases with increasing $\mathrm{pH}$ (Biernbaum and Argo, 1995; Lucas and Davis, 1961; Peterson, 1981; Wright and Niemiera, 1987). For floricultural crop species grown in a soilless medium, the most common nutrient imbalances that occur when $\mathrm{pH}$ is outside the optimum range of 5.6 to 6.2 (Bailey and Nelson, 1998) are either toxic levels of $\mathrm{Fe}$ and $\mathrm{Mn}$ at low $\mathrm{pH}$ or Fe deficiency at high pH (Albano and Miller, 1998; Argo and Fisher, 2002; Biernbaum et al.,1988; Reed, 1996).

Received for publication 13 Jan. 2003. Accepted for publication 3 Nov. 2003. This is New Hampshire Agricultural Experiment Station scientific contribution 2160. We acknowledge the University of New Hampshire Agricultural Experiment Station, Anna and Raymond Tuttle Horticultural Endowment, D.S. Cole Growers, FIRST, Greencare Fertilizers Inc., Pleasant View Gardens, The Scotts Company Inc., and Sun Gro Horticulture Inc. for supporting this research. We thank John Biernbaum, Chris Neefus, Stuart Blanchard, Leland Jahnke, and Dean Kopsell for their advice.

${ }^{1}$ Graduate research assistant.

${ }^{2}$ Associate professor and corresponding author.
The form and concentration of micronutrients applied in a water-soluble fertilizer (WSF) affect the available nutrient concentration in the soil solution across a range in $\mathrm{pH}$. Solubility of sulfate and oxide forms of metal micronutrients in peat-based media is very high at a low media $\mathrm{pH}$, but decreases rapidly as the media $\mathrm{pH}$ increases >5.5 (Peterson, 1981; Reed, 1996). Chelated metal micronutrients tend to remain soluble over a wider $\mathrm{pH}$ range, and the stability of Fe chelates at high $\mathrm{pH}(>6.5)$ is EDDHA (ethylenediaminobis(2-hydroxyphenyl)acetic acid $>>$ DTPA (diethylenetrinitrilopentaacetic acid) $>$ EDTA > HEDTA (N-(2-hydroxyeth yl)ethylenedinitrilotriacetic acid) $>>$ citrate (Boxma, 1981; Lindsay, 1979; Reed, 1996).

A review of product labels from commercially available blended water-soluble fertilizers used in North America shows that common sulfate micronutrient forms are $\mathrm{FeSO}_{4} \cdot 7 \mathrm{H}_{2} \mathrm{O}$, $\mathrm{MnSO}_{4} \cdot \mathrm{H}_{2} \mathrm{O}, \mathrm{ZnSO}_{4} \cdot \mathrm{H}_{2} \mathrm{O}$ and $\mathrm{CuSO}_{4} \cdot 5 \mathrm{H}_{2}^{2} \mathrm{O}$, and common chelated micronutrient forms are Fe-EDTA, Mn-EDTA, Zn-EDTA, and $\mathrm{Cu}$-EDTA. Iron-DTPA and Fe-EDDHA are also commercially available, but are not commonly found in blended fertilizers. Common forms of $\mathrm{B}$ and $\mathrm{Mo}$ are $\mathrm{H}_{3} \mathrm{BO}_{3}, \mathrm{Na}_{2} \mathrm{~B}_{4} \mathrm{O}_{7}$ and $\mathrm{Na}_{2} \mathrm{MoO}_{4}$.

Another factor affecting micronutrient nutrition is the concentration applied to the crop. Our review of commercially available blended water-soluble greenhouse fertilizers used in North America (Smith et al. [companion article a]) found that median micronutrient concentrations were $0.5 \mathrm{mg} \cdot \mathrm{L}^{-1} \mathrm{Fe}$ (range: 0.1 to $6 \mathrm{mg} \cdot \mathrm{L}^{-1}$ ), $0.2 \mathrm{mg} \cdot \mathrm{L}^{-1} \mathrm{Mn}$ (range: $<0.01$ to 1), $0.05 \mathrm{mg} \cdot \mathrm{L}^{-1} \mathrm{Cu}$ (range: $<0.01$ to 0.5 ), 0.1 $\mathrm{mg} \cdot \mathrm{L}^{-1} \mathrm{Zn}$ (range: $<0.01$ to $0.55 \mathrm{mg} \cdot \mathrm{L}^{-1}$ ), 0.05 $\mathrm{mg} \cdot \mathrm{L}^{-1} \mathrm{~B}$ (range: $<0.01$ to 1.0 ), and $0.03 \mathrm{mg} \cdot \mathrm{L}^{-1}$ Mo (range: $<0.001$ to $0.5 \mathrm{mg} \cdot \mathrm{L}^{-1}$ ) for every $100 \mathrm{mg} \cdot \mathrm{L}^{-1} \mathrm{~N}$. The concentration of nitrogen applied to a crop is therefore likely to affect whether the micronutrient concentrations are adequate for plant growth, or are insufficient (deficiency) or excessive (toxicity) at a particular substrate $\mathrm{pH}$.

Nutrient uptake can differ greatly from nutrient solubility because of a variety of biological factors in the rhizosphere, such as active transport mechanisms by roots, root exudation of chelating, reducing, and acidifying agents, competition and antagonisms between nutrients and other salts, and competition with soil microorganisms (Marschner, 1995). For example, Lucas and Davis (1961) and Peterson (1981) concluded that the optimal $\mathrm{pH}$ for $\mathrm{P}$ nutrition was 5.5 in media without soil, because above this $\mathrm{pH}$ water-soluble $\mathrm{P}$ concentration in the medium began to decrease. However, Adams et al. (1978) found that the P content of lettuce leaves was unaffected by medium $\mathrm{pH}$ up to 6.5, even though the concentration of water-soluble $\mathrm{P}$ measured in the medium was $38 \%$ of that measured at $\mathrm{pH}$ 5.5. Argo and Biernbaum (1996) also found that although the concentration of water-soluble $\mathrm{P}$ in the root medium decreased with increasing $\mathrm{pH}$, the effect on impatiens shoot-tissue $\mathrm{P}$ was minimal until $\mathrm{pH}$ was above 7.2.

Our goal was to quantify the effect of substrate $\mathrm{pH}$ and micronutrient concentration on tissue nutrient levels for two floricultural crop species-hybrid petunia (Petunia $\times$ hybrida Hort. Vilm.-Andr.) and hybrid impatiens (Impatiens wallerana Hook. F.). We hypothesized that the primary effect of increasing substrate $\mathrm{pH}$ would be a reduction in tissue concentrations of micronutrients (especially $\mathrm{Fe}$ ), based on existing research (Fisher et al., 2003; Miller et al., 1984; Peterson, 1981). We further hypothesized that increased micronutrient concentration in fertilizer would increase leaf chlorophyll level by increasing tissue levels of these nutrients and compensating for lower solubility at high substrate $\mathrm{pH}$. Specific objectives were to 1) quantify the effect of substrate $\mathrm{pH}$ on tissue macronutrients, 2) quantify the effect of substrate $\mathrm{pH}$ on tissue micronutrients, particularly with regard to $\mathrm{Fe}$ and $\mathrm{Mn}$, and 3) to correlate tissue nutrient levels with pigment concentration.

\section{Materials and methods}

Design. Two species, Petunia $\times$ hybrida 'Priscilla' and Impatiens wallerana 'Rosebud Purple Magic', were grown in a $70 \%$ peat : $30 \%$ perlite medium at five preplant lime incorporation rates, and irrigated using a complete WSF that contained one of 3 different micronutrient concentrations in a factorial design (five lime 
rates $\times$ three micronutrient concentrations). The experiment was a randomized, completeblock design that took place on four benches in the same greenhouse compartment, where each bench represented a block. Combinations of micronutrient concentration and lime rate were randomized within each block, and each combination contained 10 replicate pots per block. Data were analyzed using analysis of variance (ANOVA) and Tukey's mean comparison in PROC GLM of SAS (SAS Institute, Cary, N.C.). In addition, we performed linear regression analysis on medium Mn versus tissue $\mathrm{Mn}$; medium Fe versus tissue Fe (total); medium $\mathrm{Fe}$ versus tissue $\mathrm{Fe}^{2+}$; and tissue $\mathrm{Fe}$ (total) versus tissue $\mathrm{Fe}^{2+}$.

Growing conditions. Rooted cuttings were planted in $450-\mathrm{cm}^{3}$ containers (10-cm standard round pots), spaced $13.5 \mathrm{~cm}$ apart on center. The experiment took place on four $1.2 \times 4.6-\mathrm{m}$ hard plastic benches in a $6.1 \times 9.1-\mathrm{m}$ glasshouse for 4 weeks. Greenhouse air and soil temperature was measured by a Campbell CR10X datalogger (Campbell Scientific Inc., Logan, Utah) using type-T thermocouples. The air sensor was aspirated and shielded, and mean daily air temperature ( \pm standard deviation) was 21.0 ${ }^{\circ} \mathrm{C} \pm$ 0.4. Soil temperature was $20.2{ }^{\circ} \mathrm{C} \pm 1.0$. When ambient PAR (photosynthetically active radiation) light level fell below $600 \mu \mathrm{mol} \cdot \mathrm{m}^{-2} \cdot \mathrm{s}^{-1}$ between 06:30 to 17:30, we provided supplemental lighting with high-pressure sodium lamps at $46 \mu \mathrm{mol} \cdot \mathrm{m}^{-2} \cdot \mathrm{s}^{-1}$.

Growing medium. Both species were grown in a $70 \%$ (by volume) Canadian sphagnum peat (Fisons professional black bale peat, Sun Gro Horticulture, Bellevue, Wash.) and 30\% super coarse perlite (Whittemore Co., Lawrence, Mass.).Atmixing, $0.9 \mathrm{~kg} \cdot \mathrm{m}^{-3}$ of a $6 \mathrm{~N}-4 \mathrm{P}-7.5 \mathrm{~K}-$ $10 \mathrm{Ca}-1 \mathrm{Mg}-0.3 \mathrm{Fe}-0.04 \mathrm{Mn}-0.02 \mathrm{Zn}-0.036 \mathrm{Cu}-$ 0.049B-0.0097Mo preplant nutrient charge fertilizer (GreenCare Fertilizers, Inc, Chicago, Ill.) was added. Preplant nutrients were derived from $\mathrm{KNO}_{3}, \mathrm{Ca}\left(\mathrm{NO}_{3}\right)_{2}$, triple superphosphate (0N-19.8P-0K), $\mathrm{CaSO}_{4}, \mathrm{MgSO}_{4}, \mathrm{Fe}_{2} \mathrm{O}_{3}, \mathrm{MnO}_{2}$, $\mathrm{CuO}, \mathrm{H}_{3} \mathrm{BO}_{3}$, and $\left(\mathrm{NH}_{4}\right)_{6} \mathrm{Mo}_{7} \mathrm{O}_{24}$.

Type $\mathrm{N}$ microfine dolomitic hydrated lime (63.2\% $\mathrm{Ca}(\mathrm{OH}), 33.8 \% \mathrm{MgO}, 0.8 \% \mathrm{SiO}_{2}$, $0.4 \% \mathrm{H}_{2} \mathrm{O}, 0.2 \% \mathrm{Al}_{2} \mathrm{O}_{3}, 0.1 \% \mathrm{Fe}_{2} \mathrm{O}_{3}, 0.03 \% \mathrm{~S}$; $92 \%$ of which passed through a $45-\mu$ m screen, National Lime and Stone, Findlay, Ohio) was incorporated at $1.1,1.5,1.9,2.4$, or $3.1 \mathrm{~kg} \cdot \mathrm{m}^{-3}$ to give initial substrate $\mathrm{pH}$ values of ( $\mathrm{SE} \pm$ 0.01 ) 4.5, 4.8, 5.3, 6.1, and 7.2, and with initial electroconductivity (EC) of (SE \pm 0.01$) 1.1$, $1.2,1.2,1.3$, and $1.3 \mathrm{dS} \cdot \mathrm{m}^{-1}$, respectively. A deionized water solution containing $1.4 \mathrm{~mL} \cdot \mathrm{L}^{-1}$ of a wetting agent (Psi Matric, Aquatrols, Cherry Hill, N.J.) was added to all medium at $0.14 \mathrm{~L} \cdot \mathrm{m}^{-3}$, and the medium was allowed to equilibrate for $5 \mathrm{~d}$ before planting.

Fertilization. Plants were fertilized with a deionized water macronutrient solution consisting of $210 \mathrm{~N}-31 \mathrm{P}-235 \mathrm{~K}-200 \mathrm{Ca}-49 \mathrm{Mg}$ from $5 \mathrm{~mm} \mathrm{Ca}\left(\mathrm{NO}_{3}\right)_{2}, 5 \mathrm{~mm} \mathrm{KNO}_{3}, 2 \mathrm{~mm}$ $\mathrm{MgSO}_{4}$, and $1 \mathrm{~mm} \mathrm{KH} \mathrm{PO}_{4}$. Micronutrients were supplied by Compound 111 (abbreviated to C111 in this text, Scotts Co., Marysville, Ohio) EDTA-chelated micronutrient complex $\left[0.74 \% \mathrm{Mg}\left(\mathrm{MgSO}_{4}\right), 0.232 \% \mathrm{~B}\right.$ $\left(\mathrm{H}_{3} \mathrm{BO}_{3}\right), 0.1136 \% \mathrm{Cu}$ (Cu-EDTA), $1.5 \% \mathrm{Fe}$
(Fe-EDTA), 0.74\% Mn (Mn-EDTA), 0.0242\% $\mathrm{Mo}\left(\mathrm{Na}_{2} \mathrm{MoO}_{4}\right), 0.075 \% \mathrm{Zn}$ (Zn-EDTA)]. $\mathrm{C} 111$ was added to the macronutrient solution at $0.033,0.067$, or $0.134 \mathrm{~g} \cdot \mathrm{L}^{-1}$. Using $\mathrm{Fe}$ as an example, C111 supplied $0.5,1.0$ or $2.0 \mathrm{mg} \cdot \mathrm{L}^{-1}$ $\mathrm{Fe}$, respectively.

Tensiometers (Mini “LT”, Irrometer, Riverside, Calif.) were randomly placed in three pots per species. All plants of an individual species were top-watered with treatment solutions when medium dryness exceeded $-5 \mathrm{kPa}$. Each pot received $\approx 110 \mathrm{~mL}$ of solution at each irrigation, with a mean leaching rate of $<8 \%$.

Data collection. To measure $\mathrm{pH}$ and $\mathrm{EC}$, a saturated paste was prepared from the media using deionized water as the extractant (Warnke, 1995). Substrate $\mathrm{pH}$ was measured directly in the slurry, and electroconductivity was measured on the filtered extract $0,7,14$, and $21 \mathrm{~d}$ after planting from two destructively sampled replicates per block. Final $\mathrm{pH}$ and EC were collected $28 \mathrm{~d}$ after planting on all replicates. Substrate $\mathrm{pH}$ was measured using a solid-state $\mathrm{pH}$ probe (model 6165 Sure-Flow pHuture Probe; Orion Technologies, Beverly, Mass.) with a pH meter (model 620; Orion), and EC was measured with an electroconductivity meter (model 130; Orion).

Medium and tissue nutrient concentrations were quantified using inductively coupled plasma (ICP) atomic emission spectrophotometry. Samples were collected $28 \mathrm{~d}$ after planting, and the four final replications per $\mathrm{pH}$ $\times$ C111 combination within each block were combined for ICP analysis of the root medium and plant tissue.

Tissue nutrients. Tissue harvested from each pot was rinsed in a distilled water solution containing $0.5 \%$ nonionic, phosphate-free detergent (Aquet, Bel-Art, Pequannoc, N.J.). Plant leaves were separated from petioles and stems, and dried in a $50{ }^{\circ} \mathrm{C}$ oven for $7 \mathrm{~d}$. Dried tissue was ground in a Thomas-Wiley grinding mill in order to pass through a 40-mesh screen. Ten milliliters of $\mathrm{HNO}_{3}$ was added to $0.3 \mathrm{~g}$ of ground tissue and microwave digested for 15 min while ramping to $170{ }^{\circ} \mathrm{C}$, and then for another $15 \mathrm{~min}$ at $170{ }^{\circ} \mathrm{C}$. The sample was diluted to $50 \mathrm{~mL}$ with distilled, deionized water, and nutrient concentrations were determined using the ICP. Molybdenum levels were not measured with adequate precision, and are not reported.

Active Fe. Oserkowsky (1933) and Bennett (1945) found that extracting the physiologically active ferrous iron $\left(\mathrm{Fe}^{2+}\right)$ with dilute $\mathrm{HCl}$ provided a more accurate diagnosis of $\mathrm{Fe}$ nutritional status in leaf tissue than total Fe. Ferrous Fe was determined according to the method of Oserkowsky (1933), which was modified by Llorente et al. (1976). We added $10 \mathrm{~mL}$ of $1 \mathrm{~N} \mathrm{HCl}$ to $0.5 \mathrm{~g}$ of dried tissue in a 15 -mL centrifuge tube placed horizontally on an orbital shaker (VWRbrand, So. Plainfield, N.J.) and shaken for $4 \mathrm{~h}$ at $2.0 \mathrm{r} \cdot \mathrm{s}^{-1}$. Samples were centrifuged at $167 \mathrm{r} \cdot \mathrm{s}^{-1}$ for $30 \mathrm{~min}$, then the upper phase of the solution was filtered twice through filter paper (no. 1, Whatman paper, Maidstone, Kent, U.K.) using a buchner funnel under vacuum extraction. The Fe level in the filtrate was analyzed by ICP.
Comparison between SPAD and tissue nutrient levels. The Minolta SPAD meter (Soil Plant Analysis Development, Ramsey, N.J.) indirectly measures chlorophyll content in a nondestructive manner. SPAD measurements were taken on 10 random leaves per plant and were reported in detail by Smith et al. ([companion article a]). To correlate tissue nutrient levels and chlorosis, we compared the levels of tissue nutrients with measured SPAD values. The nonlinear procedure in SAS (SAS Institute, Cary, N.C.) was used to fit an empirical model to data for each species using equations based on Anderson and Nelson (1975). We fit two alternative linear models to each nutrient, where Nutr represented the foliar concentration of the nutrient:

1. One phase: There was a linear relationship $\left(a+b_{1}\right.$ Nutr $)$ between the nutrient and SPAD index, fitted using linear regression to estimate $a$ and $b_{l}$.

2. Two phase: a) Below a critical nutrient level Nutr ${ }_{\text {crit }}$, a positive linear relationship $(a+$ $b_{l}$ Nutr) described the effect of the nutrient on SPAD index up to a critical SPAD value $\left(C_{\text {crit }}\right)$, and b) above $N u t r_{c r i t}$, the slope changed to a linear relationship with a different gradient $\left(C_{c r i t}\right.$ $\left.+b_{2}\left(N u t r-N u t r_{c r i t}\right)\right)$ with nutrient concentration, possibly because of nutrient saturation or toxicity. Four parameters $\left(a_{1}, b_{1}, b_{2}\right.$, and Nutr $\left.r_{\text {crit }}\right)$ were estimated by the nonlinear procedure. $C_{\text {crit }}$ was calculated from $a+b_{l} N u t r_{c r i t}$.

We reported one model for each nutrient. If a unique statistical solution existed for all parameters for both model 1 and model 2, as estimated by SAS, we selected the model with 1) the highest adjusted $r^{2}$ or 2) the fewest parameters (i.e., model 1) if adjusted $r^{2}$ was equal for more than one model.

\section{Results and Discussion}

pH and clectroconductivity. Substrate $\mathrm{pH}$ and EC data for this experiment were presented by Smith et al. ([companion article a]). Petunia tended to have a slightly higher substrate $\mathrm{pH}$ (by up to 0.2 units at a given lime rate) than impatiens, however C111 did not affect substrate $\mathrm{pH}$. For petunia, the least-square mean $\mathrm{pH}$ values of the lime treatments over time (SE \pm 0.02 ) were $4.6,4.9,5.3,6.1$, and $7.0 \mathrm{pH}$ units, whereas for impatiens the mean $\mathrm{pH}$ values were 4.4, 4.7, 5.1, 6.0, and 7.0. Substrate EC remained within acceptable ranges (Warncke, 1995) throughout the experiment, and increased from an average $1.2 \mathrm{dS} \cdot \mathrm{m}^{-1}$ at planting to 2.29 , 2.45 , and $2.57 \mathrm{dS} \cdot \mathrm{m}^{-1}$ at the end of the experiment for the $0.033,0.067$, and $0.134 \mathrm{~g} \cdot \mathrm{L}^{-1} \mathrm{C} 111$ treatments, respectively.

Foliar macronutrients. Substrate $\mathrm{pH}$ affected all foliar macronutrient concentrations (Table 1). Foliar N content decreased slightly as substrate $\mathrm{pH}$ increased (by $<10 \%$ from the lowest to highest $\mathrm{pH}$ level), whereas foliar $\mathrm{Ca}$, $\mathrm{Mg}$ and $\mathrm{S}$ tended to increase. The increase in foliar $\mathrm{Ca}$ and $\mathrm{Mg}$ with increasing substrate $\mathrm{pH}$ probably resulted from additional dolomitic lime used to achieve the higher substrate $\mathrm{pH}$ treatments. Although foliar $\mathrm{P}$ and $\mathrm{K}$ varied with $\mathrm{pH}$, there was no consistent trend between species. Increasing C 111 concentration decreased 
$\mathrm{P}$ overall with petunia, but in impatiens there was a significant interaction, whereby increasing $\mathrm{C} 111$ resulted in a decline in $\mathrm{P}$ at low $\mathrm{pH}$ and an increase in $\mathrm{P}$ at high $\mathrm{pH}$. Given the number of nutrients statistically analyzed for this experiment, however, the interaction for $\mathrm{P}$ may not be horticulturally significant.

Foliar macronutrients were generally within the acceptable ranges for bedding plant species used by testing laboratories (including the survey range from Mills and Jones (1996) in Table 1, and ranges reported by Vetanovetz (1996)). Differences between observed levels and suggested nutrient ranges (for example high observed $\mathrm{N}$ content for impatiens) may indicate that the published ranges may not accurately reflect toxic or deficient levels for these particular cultivars. Differences between our results and other ranges may have resulted from our tissue sampling method, however, because all foliage was included in the analysis whereas commercial testing laboratories generally sample recently mature leaves (Vetanovetz, 1996).

Foliar micronutrients. Substrate $\mathrm{pH}$ affected all foliar micronutrient levels (Table 2). In both species, total $\mathrm{Fe}$ and ferrous Fe consistently decreased as substrate $\mathrm{pH}$ increased. Ferrous Fe in tissue was positively correlated with total $\mathrm{Fe}$ in tissue for both species $(p<$ 0.001 , data not shown). For petunia, foliar contents of $\mathrm{Zn}$ and $\mathrm{B}$ increased as $\mathrm{pH}$ rose, whereas $\mathrm{Cu}$ content decreased. $\mathrm{Zn}$ increased in impatiens as substrate $\mathrm{pH}$ increased.

Foliar Mn did not change significantly as pH increased to 6 (Table 1), but when substrate pH increased from 6 to 7, the mean Mn content increased for both petunia (by $80 \%$ compared with pH 6) and impatiens (37\%). Biernbaum and Argo (1995) reported a similar trend for impatiens grown at a wide $\mathrm{pH}$ range and irrigated with $3 \mathrm{WSF}$ differing in $\mathrm{NH}_{4}$ to $\mathrm{NO}_{3}$ ratio, $\mathrm{Ca}, \mathrm{Mg}$, and $\mathrm{S}$ content, but containing the same micronutrients concentrations. Foliar Mn in the Biernbaum and Argo (1995) study decreased from $\mathrm{pH} 4.0$ to 6.0 , then increased as medium $\mathrm{pH}$ rose from 6.0 to 8.5. The ratio of $\mathrm{Fe}$ to $\mathrm{Mn}$ in plant tissue, two nutrients that can have antagonistic effects on uptake (Bunt, 1988; Mills and Jones, 1996), decreased with increasing substrate $\mathrm{pH}$ in both species.

Increasing the concentration of $\mathrm{C} 111$ led to a higher foliar content of total $\mathrm{Fe}$ (impatiens only), ferrous $\mathrm{Fe}$, and $\mathrm{Cu}$ in both species (Table 2 ), and increased the ratio of Fe to Mn. Higher concentrations of C111 decreased foliar Mn in petunia, but impatiens foliar Mn was not

Table 1. Summary ANOVA table showing the effects of Compound 111 EDTA-chelated micronutrient complex (C111) and substrate pH (least-square mean over time) on tissue macronutrient content $\left(\left(\mu \mathrm{g} \cdot \mathrm{g}^{-1}\right.\right.$ dry tissue) for petunia and impatiens. Species were analyzed separately. Tissue was collected $28 \mathrm{~d}$ after planting from four replicate samples, with each sample combining tissue from four plants.

\begin{tabular}{|c|c|c|c|c|c|c|c|c|c|c|c|c|}
\hline \multirow[b]{2}{*}{ Substrate } & \multicolumn{6}{|c|}{ Petunia } & \multicolumn{6}{|c|}{ Impatiens } \\
\hline & $\mathrm{N}$ & $\mathrm{P}$ & $\mathrm{K}$ & $\mathrm{Ca}$ & $\mathrm{Mg}$ & $\mathrm{S}$ & $\mathrm{N}$ & $\mathrm{P}$ & $\mathrm{K}$ & $\mathrm{Ca}$ & $\mathrm{Mg}$ & $S$ \\
\hline Substrate $\mathrm{pH}$ & $* * *$ & $*$ & $* * *$ & $* *$ & $* * *$ & $* * *$ & $* * *$ & $* *$ & $* *$ & $* *$ & $* * *$ & $* * *$ \\
\hline
\end{tabular}

Substrate $\mathrm{pH}$

\begin{tabular}{l}
\hline .6 \\
4.9 \\
5.3 \\
6.1 \\
7.0
\end{tabular}

Least-square means

Substrate $\mathrm{pH}$

Least-square means

\begin{tabular}{|c|c|c|c|c|c|c|c|c|c|c|c|c|}
\hline $0 \mathrm{a}$ & $7152 \mathrm{ab}$ & 521 & $17901 \mathrm{ab}$ & $10746 \mathrm{bc}$ & $3276 \mathrm{bc}$ & 4.4 & $200 \mathrm{a}$ & $6142 \mathrm{ab}$ & $21925 \mathrm{a}$ & $186 \mathrm{~b}$ & $12531 \mathrm{c}$ & $1948 \mathrm{c}$ \\
\hline 24 & 70 & $50662 \mathrm{bc}$ & $16908 \mathrm{~b}$ & $11273 b c$ & $3061 \mathrm{c}$ & 4.7 & $66400 \mathrm{a}$ & $6486 \mathrm{ab}$ & $21440 \mathrm{a}$ & $22216 \mathrm{a}$ & $13639 \mathrm{bc}$ & $72 \mathrm{bc}$ \\
\hline 50 & $7679 a b$ & $48966 \mathrm{c}$ & $16491 \mathrm{~b}$ & $11793 \mathrm{c}$ & 306 & 5.1 & $00 \mathrm{a}$ & 58 & 19999 ab & 21 & bc & \\
\hline $000 \mathrm{ab}$ & & $53595 \mathrm{ab}$ & $17394 \mathrm{ab}$ & $13690 \mathrm{ab}$ & $3570 \mathrm{~b}$ & 6.0 & $63310 \mathrm{~b}$ & $6405 \mathrm{ab}$ & $19064 \mathrm{~b}$ & 217 & $4120 \mathrm{~b}$ & \\
\hline OS & & $7594 \mathrm{~g}$ & 19267 & 15262 & $4104 \mathrm{a}$ & 7.0 & $44280 \mathrm{~b}$ & 6 a & 1 & $\mathrm{a}$ & $16941 \mathrm{a}$ & \\
\hline
\end{tabular}

C111 concn $\left(\mathrm{g} \cdot \mathrm{L}^{-1}\right)$

Least-square means

C111 concn $\left(\mathrm{g} \cdot \mathrm{L}^{-1}\right)$

Least-square means

\begin{tabular}{|c|c|c|c|c|c|c|c|c|c|c|c|c|c|}
\hline 0.033 & 59660 a & $7800 \mathrm{a}$ & $54206 \mathrm{a}$ & $18166 \mathrm{a}$ & $12764 \mathrm{ab}$ & $3561 \mathrm{a}$ & 0.033 & $65600 \mathrm{a}$ & $6471 \mathrm{a}$ & $21304 \mathrm{a}$ & $21704 \mathrm{a}$ & $14158 \mathrm{a}$ & $6378 \mathrm{a}$ \\
\hline Survey range $\min ^{2}$ & 38500 & 4700 & 31300 & 12000 & 3600 & 3300 & & 36400 & 7700 & 13700 & 17500 & 8900 & 8300 \\
\hline Survey range max & 76000 & 9300 & 66500 & 28100 & 13700 & 8000 & & 58300 & 9200 & 23500 & 24000 & 36400 & 8700 \\
\hline
\end{tabular}

${ }^{2}$ Minimum and maximum values reported by Mills and Jones (1996) for each species.

Ns, $, * * *, * * *$ Nonsignificant or significant at $P \leq 0.05,0.01$, or 0.001 , respectively. Letters after each treatment mean represent mean separation using Tukey's HSD at $p=0.05$.

Table 2. Summary ANOVA table showing the effects of Compound 111 EDTA-chelated micronutrient complex (C111) and substrate pH (least-square mean over time) on tissue micronutrient content ( $\mu \mathrm{g} \cdot \mathrm{g}^{-1}$ dried tissue) for petunia and impatiens. Species were analyzed separately. Tissue was collected $28 \mathrm{~d}$ after planting from four replicate samples, with each sample combining tissue from 4 plants.

\begin{tabular}{|c|c|c|c|c|c|c|c|c|c|c|c|c|c|c|c|}
\hline \multirow[b]{2}{*}{ Parameter } & \multicolumn{7}{|c|}{ Petunia } & & \multicolumn{7}{|c|}{ Impatiens } \\
\hline & $\mathrm{Fe}$ & $\mathrm{Fe}^{2+}$ & $\mathrm{Mn}$ & $\mathrm{Fe}: \mathrm{Mn}^{2}$ & $\mathrm{Cu}$ & $\mathrm{Zn}$ & B & & $\mathrm{Fe}$ & $\mathrm{Fe}^{2+}$ & $\mathrm{Mn}$ & Fe:Mn & $\mathrm{Cu}$ & $\mathrm{Zn}$ & B \\
\hline Substrate $\mathrm{pH}$ & $* * *$ & $* * *$ & $* * *$ & $* * *$ & $* * *$ & $* * *$ & $* * *$ & & $* * *$ & $* * *$ & $* * *$ & $* * *$ & ** & * & * \\
\hline \multicolumn{3}{|l|}{ Substrate $\mathrm{pH}$} & \multicolumn{4}{|c|}{ Least-square means } & \multicolumn{3}{|c|}{ Substrate $\mathrm{pH}$} & \multicolumn{5}{|c|}{ Least-square means } & \\
\hline 4.6 & $159 \mathrm{a}$ & $81 \mathrm{a}$ & $155 \mathrm{~b}$ & $1.02 \mathrm{a}$ & $14 \mathrm{a}$ & $75 \mathrm{c}$ & $36 \mathrm{abc}$ & 4.4 & $146 \mathrm{a}$ & $97 \mathrm{a}$ & $218 \mathrm{~b}$ & $0.67 \mathrm{a}$ & $9 \mathrm{ab}$ & $22 \mathrm{~b}$ & $39 \mathrm{a}$ \\
\hline 4.9 & $130 \mathrm{~b}$ & $69 \mathrm{ab}$ & $153 \mathrm{~b}$ & $0.85 \mathrm{~b}$ & $13 \mathrm{a}$ & $83 \mathrm{bc}$ & $29 \mathrm{c}$ & 4.7 & $138 \mathrm{a}$ & $91 \mathrm{a}$ & $226 \mathrm{~b}$ & $0.61 \mathrm{ab}$ & $11 \mathrm{a}$ & $25 \mathrm{ab}$ & $39 \mathrm{a}$ \\
\hline 7.0 & 91d & $38 \mathrm{c}$ & $257 \mathrm{a}$ & $0.34 \mathrm{~d}$ & $8 \mathrm{~b}$ & $127 \mathrm{a}$ & $43 \mathrm{a}$ & 7.0 & $100 \mathrm{~b}$ & $58 \mathrm{c}$ & $265 \mathrm{a}$ & $0.38 \mathrm{~d}$ & $8 \mathrm{~b}$ & $46 \mathrm{a}$ & $26 \mathrm{~b}$ \\
\hline \multicolumn{3}{|l|}{ C111 concn $\left(\mathrm{g} \cdot \mathrm{L}^{-1}\right)$} & \multicolumn{4}{|c|}{ Least-square means } & \multicolumn{3}{|c|}{$\mathrm{C} 111 \operatorname{concn}\left(\mathrm{g} \cdot \mathrm{L}^{-1}\right)$} & \multicolumn{5}{|c|}{ Least-square means } & \\
\hline$\overline{0.033}$ & $113 \mathrm{a}$ & $51 \mathrm{~b}$ & $185 \mathrm{a}$ & $0.65 \mathrm{~b}$ & $10 \mathrm{~b}$ & $98 \mathrm{a}$ & $37 \mathrm{a}$ & 0.033 & $103 \mathrm{~b}$ & $67 \mathrm{~b}$ & $224 \mathrm{a}$ & $0.46 \mathrm{c}$ & $8 \mathrm{~b}$ & $24 \mathrm{a}$ & $28 \mathrm{~b}$ \\
\hline 0.067 & $123 \mathrm{a}$ & $63 \mathrm{a}$ & $173 \mathrm{ab}$ & $0.75 \mathrm{a}$ & $10 \mathrm{~b}$ & $111 \mathrm{a}$ & $35 \mathrm{a}$ & 0.067 & $123 \mathrm{~b}$ & $74 \mathrm{~b}$ & $223 \mathrm{a}$ & $0.56 \mathrm{~b}$ & $9 \mathrm{~b}$ & $31 \mathrm{a}$ & $34 \mathrm{ab}$ \\
\hline 0.134 & $126 \mathrm{a}$ & $65 \mathrm{a}$ & $171 \mathrm{~b}$ & $0.82 \mathrm{a}$ & $13 \mathrm{a}$ & $94 \mathrm{a}$ & $35 \mathrm{a}$ & 0.134 & $136 \mathrm{a}$ & $92 \mathrm{a}$ & 219 a & $0.63 \mathrm{a}$ & $11 \mathrm{a}$ & $36 \mathrm{a}$ & $40 \mathrm{a}$ \\
\hline Survey range $\min ^{y}$ & 84 & $N / A^{x}$ & 44 & N/A & 3 & 25 & 18 & & 107 & N/A & 329 & N/A ${ }^{x}$ & 20 & 57 & 23 \\
\hline
\end{tabular}

${ }^{\mathrm{y}}$ Ratio between total Fe and total Mn in the leaf tissue.

${ }^{2}$ Minimum and maximum values reported by Mills and Jones (1996) for each species. Survey data not available for ferrous iron or Fe:Mn.

${ }^{\times} \mathrm{N} / \mathrm{A}=$ not applicable.

${ }_{\mathrm{Ns}, * * *, * * * *}$ Nonsignificant or significant at $P \leq 0.05,0.01$, or 0.001 , respectively. Letters after each treatment mean represent mean separation using Tukey's HSD at $p=0.05$. 


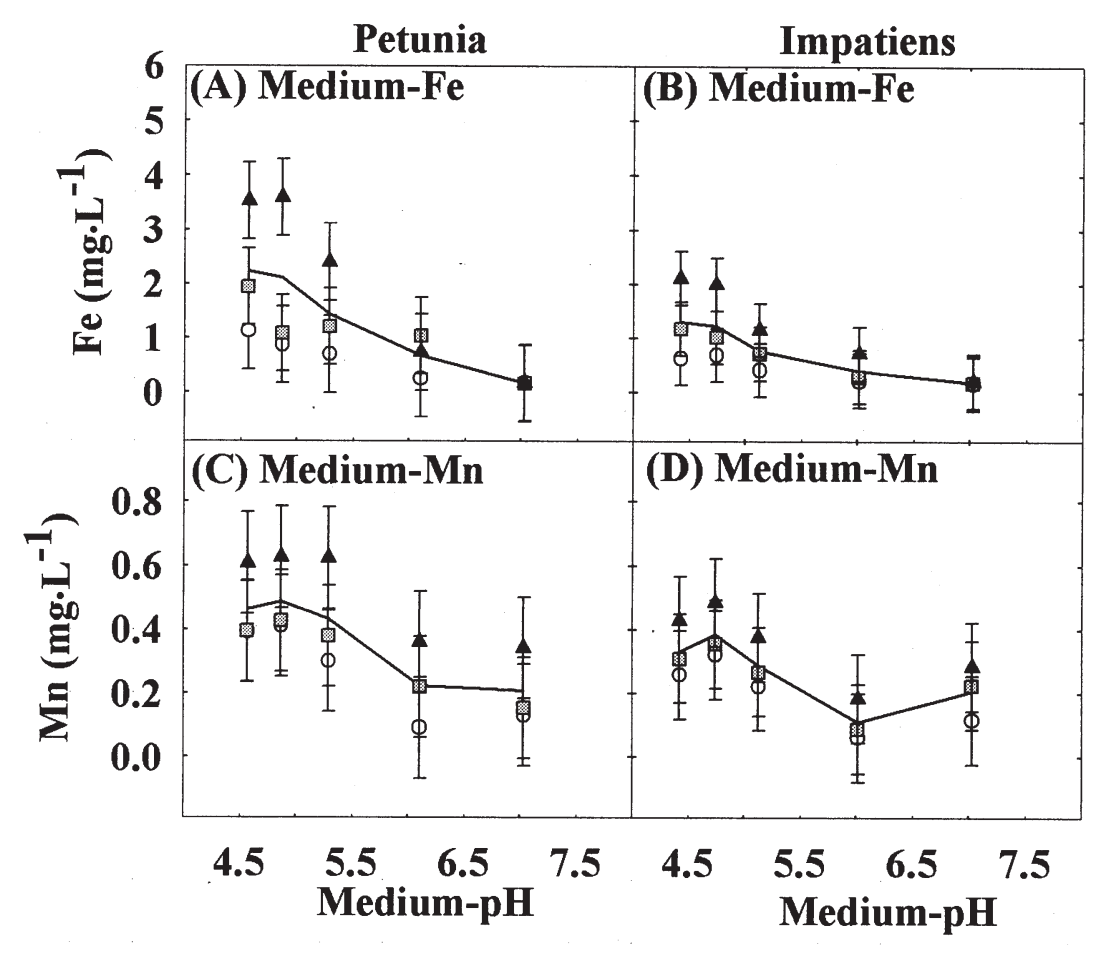

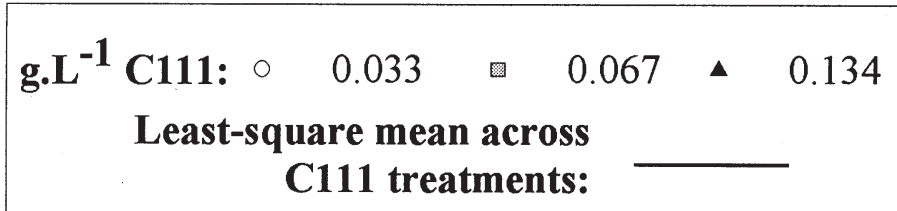

Table 3. Regression of foliar nutrient concentration and SPAD chlorophyll index. Two models were fit for each nutrient for each species: either a single straight line $\left(a+b_{l}\right.$ Nutr, where Nutr represented the nutrient concentration in $\mu \mathrm{g} \cdot \mathrm{g}^{-1}$ ), or a two-line model (for Nutr $\leq$ Nutr ${ }_{\text {crit }}, a+b_{l}$ Nutr; for Nutr $>$ Nutr ${ }_{\text {crit }}$, $\left.a+b_{1} N u t r_{c r i t}+b_{2}\left(N u t r-N u t r_{c r i t}\right)\right)$. Adjusted $\mathrm{r}^{2}$ was higher for the two-line model than the one-line model for $\mathrm{B}, \mathrm{Fe}, \mathrm{Fe}^{2+}, \mathrm{Mg}, \mathrm{Mn}$, and $\mathrm{Fe}$ to $\mathrm{Mn}$ ratio for petunia, and $\mathrm{B}, \mathrm{Fe}, \mathrm{Fe}^{2+}, \mathrm{Mg}$, and $\mathrm{Fe}$ to $\mathrm{Mn}$ ratio for impatiens. Data were collected $28 \mathrm{~d}$ after transplanting, and the model was fit to combined data for each species from all $\mathrm{pH}$ and $\mathrm{C} 111$ levels $(\mathrm{n}=60)$.

\begin{tabular}{|c|c|c|c|c|c|}
\hline \multirow[b]{2}{*}{ Species } & \multirow[b]{2}{*}{$r^{2}$} & \multicolumn{4}{|c|}{ Parameter estimates } \\
\hline & & $\begin{array}{c}a \\
\text { (intercept) }\end{array}$ & $\begin{array}{c}b_{1} \\
\left(1^{\text {st }} \text { gradient }\right)\end{array}$ & $\begin{array}{c}B_{2} \\
\left(2^{\text {nd }} \text { gradient }\right)\end{array}$ & $\begin{array}{l}\text { Nutr } \\
\text { crit } \\
\text { nutrient levelitical }\end{array}$ \\
\hline \multicolumn{6}{|l|}{ Petunia $\left(\mu \mathrm{g} \cdot \mathrm{g}^{-1}\right)$} \\
\hline $\mathrm{N}$ & 0.25 & -43.18 & 0.001437 & --- & --- \\
\hline $\mathrm{P}$ & NS & --- & --- & --- & --- \\
\hline K & 0.34 & 83.45 & 0.000784 & --- & --- \\
\hline $\mathrm{Ca}$ & 0.22 & 71.98 & 0.00169 & --- & --- \\
\hline $\mathrm{Mg}$ & 0.48 & 47.46 & 0.000216 & 0.00355 & 13065 \\
\hline $\mathrm{S}$ & 0.47 & 70.27 & -0.00822 & --- & -- \\
\hline $\mathrm{Fe}$ & 0.51 & 4.38 & 0.353 & 0.042 & 112.1 \\
\hline $\mathrm{Fe}^{2+}$ & 0.46 & 25.06 & 0.319 & 0.041 & 64.0 \\
\hline $\mathrm{Mn}$ & 0.69 & 42.30 & 0.019 & -0.14 & 170.0 \\
\hline $\mathrm{Zn}$ & 0.15 & 50.46 & -0.082 & --- & --- \\
\hline $\mathrm{Cu}$ & 0.37 & 29.95 & 1.10 & --- & --- \\
\hline B & 0.28 & -13.27 & 2.73 & -0.42 & 22.4 \\
\hline Fe:Mn (unitless) & 0.83 & 17.94 & 38.43 & 2.69 & 0.71 \\
\hline \multicolumn{6}{|l|}{ Impatiens $\left(\mu \mathrm{g} \cdot \mathrm{g}^{-1}\right)$} \\
\hline $\mathrm{N}$ & 0.13 & -26.99 & 0.001197 & --- & --- \\
\hline $\mathrm{P}$ & 0.09 & 70.21 & -0.00301 & --- & --- \\
\hline $\mathrm{K}$ & NS & --- & --- & --- & --- \\
\hline $\mathrm{Ca}$ & NS & --- & --- & --- & --- \\
\hline $\mathrm{Mg}$ & 0.25 & 49.14 & 0.000267 & -0.00340 & 14821 \\
\hline $\mathrm{S}$ & 0.17 & 61.83 & -0.00172 & --- & --- \\
\hline $\mathrm{Fe}$ & 0.44 & 16.41 & 0.33 & 0.061 & 106.0 \\
\hline $\mathrm{Fe}^{2+}$ & 0.42 & 19.75 & 0.52 & 0.09 & 58.3 \\
\hline $\mathrm{Mn}$ & NS & --- & --- & --- & --- \\
\hline $\mathrm{Zn}$ & NS & --- & --- & --- & --- \\
\hline $\mathrm{Cu}$ & 0.10 & 42.94 & 0.875 & --- & --- \\
\hline B & 0.21 & 28.72 & 0.85 & -0.037 & 28.5 \\
\hline Fe:Mn (unitless) & 0.54 & 25.15 & 50.87 & 6.33 & 0.57 \\
\hline
\end{tabular}

${ }^{\text {ss Nonsignificant. }}$
Fig. 1. The effect of substrate $\mathrm{pH}$ and fertilizer micronutrient concentration (C111) on the concentration of $\mathrm{Fe}$ and $\mathrm{Mn}$ in the medium 28 $\mathrm{d}$ after transplant, measured in a saturated paste prepared from the medium using deionized water as the extractant: (A) Fe and (B) Mn, for petunia and impatiens $28 \mathrm{~d}$ after planting. Solid lines represent least-square means for each $\mathrm{pH}$. Symbols represent least-square means for each C111 treatment (four replications) $\pm 95 \%$ confidence intervals $\left(\bigcirc 0.033 \mathrm{~g} \cdot \mathrm{L}^{-1}, \mathbf{\square} 0.067 \mathrm{~g} \cdot \mathrm{L}^{-1}\right.$, and $\left.\boldsymbol{\Delta} 0.134 \mathrm{~g} \cdot \mathrm{L}^{-1}\right)$.

affected by $\mathrm{C} 111$. Higher concentrations of C111 led to higher foliar B in impatiens, but did not affect petunia foliar B or Zn.

Medium Fe and Mn. Substrate $\mathrm{pH}, \mathrm{C} 111$, and their interaction affected the total Fe and Mn concentration in the root medium in both species, except for $\mathrm{Mn}$ in impatiens where there was no interaction. Soluble Fe in the growing medium decreased as substrate $\mathrm{pH}$ increased (Fig. 1A and B), consistent with published research on nutrient solubility in a soilless medium (Peterson, 1981). The lower the substrate $\mathrm{pH}$, the greater the effect of $\mathrm{C} 111$ on increasing $\mathrm{Fe}$ in the medium (Fig. 1A and B), and at $\mathrm{pH} 7.0 \mathrm{C} 111$ concentration did not affect medium $\mathrm{Fe}$. Medium $\mathrm{Fe}$ and tissue $\mathrm{Fe}$ (both total $\mathrm{Fe}$ and ferrous $\mathrm{Fe}$ ) were positively linearly correlated for both species $(p<0.001$, data not shown).

Medium Mn also decreased as substrate $\mathrm{pH}$ increased (Fig. 1C and D). In contrast with medium $\mathrm{Fe}$, however, the high $(0.134$ $\left.\mathrm{g} \cdot \mathrm{L}^{-1}\right) \mathrm{C} 111$ treatment resulted in increased medium $\mathrm{Mn}$ across the entire $\mathrm{pH}$ range. $\mathrm{Mn}$ in the medium and tissue were not correlated for either impatiens or petunia.

One aspect of EDTA-chelated micronutrients (as used in C111) is that Fe-EDTA becomes unstable in the medium solution above pH 6.5 (Lindsay, 1979). Evidence for this instability was found in the reduced $\mathrm{Fe}$ levels in the root medium at high substrate $\mathrm{pH}$ (Fig. 1). Problems exist, however, in correlating soil chemical equilibrium relationships with the measured nutrient levels in medium and tissue. The nutrient concentration in the root medium of a growing crop is the result of both solubility and uptake by plant roots. In addition, correlations between the medium and tissue nutrients may be poor because the medium nutrient content is a measure of availability at one point in time, whereas the tissue content is the result of nutrient accumulation over an extended growing period.

The pattern of foliar Mn concentration may have been caused by a combination of soil chemistry (for example, Mn-EDTA is more stable than Fe-EDTA at pH 7 (Norvell, 1991)) and an antagonistic interaction between uptake of Fe and Mn (Marschner, 1995). We have seen a similar tissue Mn increase at high substrate $\mathrm{pH}$ consistently in other unpublished experiments with petunia, which have also used the EDTA-chelated form of micronutrients, and the high Mn content in tissue at substrate $\mathrm{pH}$ above 6.5 is consistently associated with low tissue Fe content. Furthermore, we have observed that the tissue $\mathrm{Mn}$ content at high $\mathrm{pH}$ can decline following a corrective soil drench 


\section{Petunia}

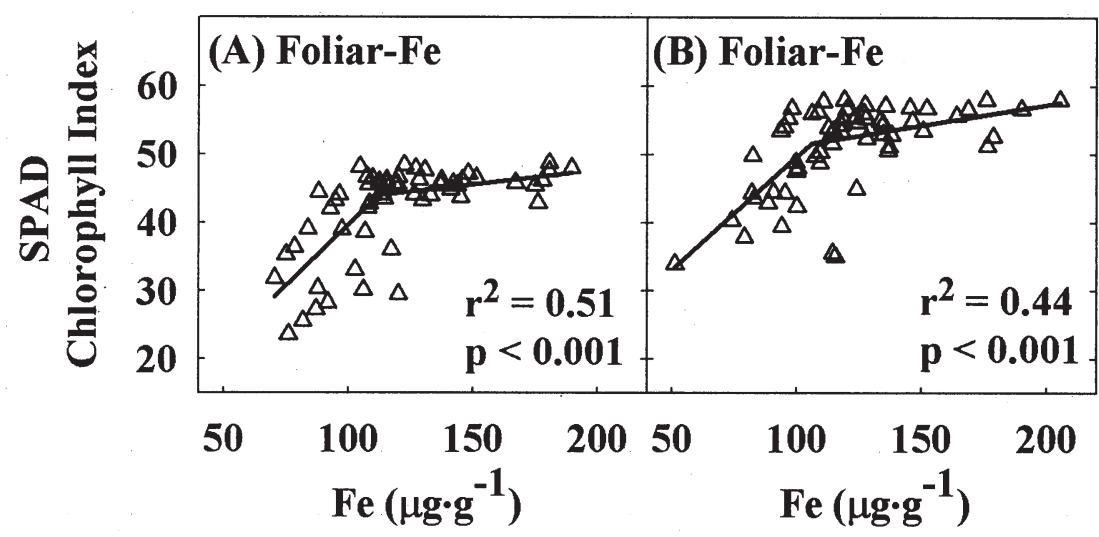

100150200250300350100150200250300350 $\operatorname{Mn}\left(\mu \mathrm{g} \cdot \mathrm{g}^{-1}\right) \quad \mathrm{Mn}\left(\mu \mathrm{g} \cdot \mathrm{g}^{-1}\right)$

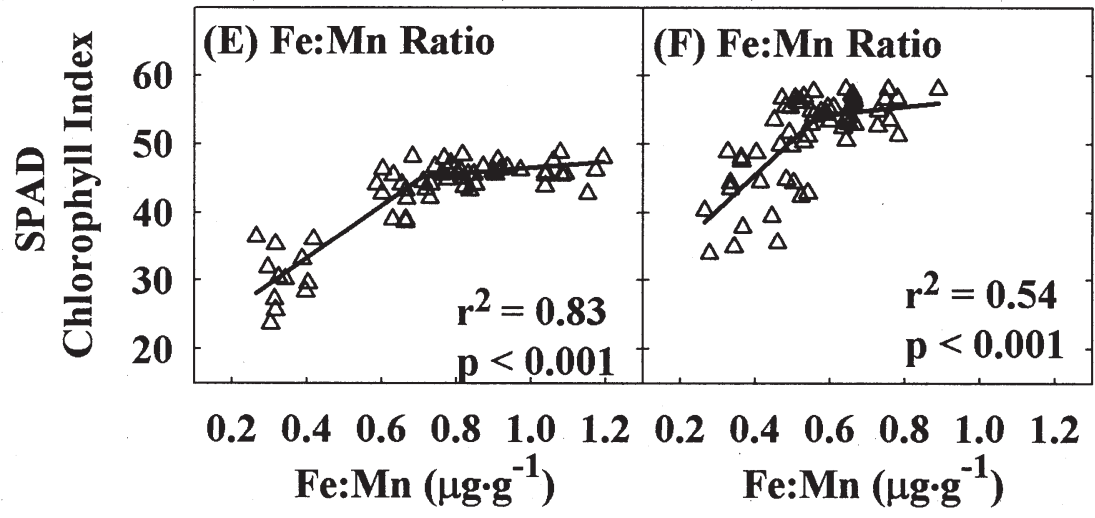

Fig. 2. Regression analysis of the SPAD chlorophyll index versus the total tissue-Fe (A and B), or Mn (C and $\mathbf{D})$, and the Fe to $\mathrm{Mn}$ ratio $(\mathbf{E}$ and $\mathbf{F})$ in leaf tissue for petunia and impatiens $28 \mathrm{~d}$ after transplant. The solid line was fit using a two-line model where below a critical nutrient level Nutr ${ }_{c r i t}$, a positive linear relationship $\left(a+b_{l} N u t r\right)$ described the effect of the nutrient on SPAD chlorophyll index to a critical SPAD value $\left(C_{c r i t}\right)$, and above $N u t r_{c r i t}$, the slope changed in a linear relationship with a different gradient $\left(C_{\max }+b_{2}\left(N u t r-N u t r_{c r i t}\right)\right)$ with nutrient concentration, presumably because of saturation. Data were collected $28 \mathrm{~d}$ after transplanting, and the model was fit to combined data from all $\mathrm{pH}$ and $\mathrm{C} 111$ treatments for each species $(n=60)$.

with Fe-EDDHA or Fe-DTPA, suggesting an antagonism with $\mathrm{Fe}$ is occurring.

Nutrient level versus SPAD. In a companion article (Smith et al. [companion article a]), chlorosis (defined as a visually obvious decrease in green color of leaves, and measured by decline in SPAD chlorophyll index below 40 in petunia and 50 in impatiens) was reported in both species at $\mathrm{pH} 6.1$ and 7.0. Chlorosis did not occur in the $\mathrm{pH}$ range 4.4 to $5.3 \mathrm{using}$ a micronutrient concentration similar to that of the micronutrient concentration for the median fertilizer described above at $100 \mathrm{mg} \cdot \mathrm{L}^{-1}$
$\mathrm{N}$. The chlorosis diminished at $\mathrm{pH} 6.1$ or 7.0 when the applied micronutrient concentration was increased.

From regression analysis of the foliar concentration of each nutrient against SPAD chlorophyll index (Table 3), the highest $r^{2}$ for petunia occurred for the Fe:Mn ratio, $\mathrm{Mn}$, and total Fe. Correlation coefficients were lower overall for impatiens compared with petunia. For impatiens, the highest $r^{2}$ occurred with Fe to $\mathrm{Mn}$ ratio, total $\mathrm{Fe}$, and $\mathrm{Fe}^{2+}$ and there was no significant correlation with $\mathrm{Mn}$. For both species, SPAD was positively correlated with tissue total Fe, up to $N u t r_{\text {crit }}\left(112 \mu \mathrm{g} \cdot \mathrm{g}^{-1}\right.$ for petunia and $106 \mu \mathrm{g} \cdot \mathrm{g}^{-1}$ for impatiens, Table 3 , Fig. 2A and B) and above Nutr SPAD values changed only slightly as Fe level increased. The nonlinear regression curve therefore indicated that when total Fe level in tissue was below 112 $\mu \mathrm{g} \cdot \mathrm{g}^{-1}$ for petunia, or $106 \mu \mathrm{g} \cdot \mathrm{g}^{-1}$ for impatiens, Fe was limiting and there was a decrease in SPAD with the corresponding increase in chlorosis. Petunia SPAD values were stable (i.e., the gradient parameter, $b$, had a low value at 0.02) as foliar Mn increased up to a Nutr of $170 \mu \mathrm{g} \cdot \mathrm{g}^{-1}$, and above Nutr foliar Mn was negatively correlated with SPAD (Fig. 2C). There was no significant relationship between SPAD and foliar Mn for impatiens (Fig. 2D). Tissue Fe:Mn ratio and SPAD were strongly correlated for both species (Figure 2E, F), with a positive trend up to $\mathrm{Nutr}_{\text {crit }}$, and a leveling of as the $\mathrm{Fe}$ to $\mathrm{Mn}$ ratio increased above $\mathrm{Nutr}_{\text {crit }}$. Nonlinear regression analysis estimated that there was a decrease in SPAD when the Fe to $\mathrm{Mn}$ ratio was below 0.71 for petunia and 0.57 for impatiens.

Because substrate $\mathrm{pH}$ affected all nutrients, and because $\mathrm{C} 111$ included all micronutrients, nutrient correlations should not be interpreted as directly causing chlorosis. In fact, it is likely that there were a combination of factors interacting to affect the observed chlorosis. Based on our analysis, however, Fe and Mn interactions appeared to have the greatest influence on chlorophyll content.

\section{Conclusions}

Research on nutrient solubility in a soilless medium in an experiment without plants by Peterson (1981) showed a strong decline in $\mathrm{P}, \mathrm{Mn}, \mathrm{Fe}, \mathrm{B}$, and $\mathrm{Zn}$ as $\mathrm{pH}$ increased from 4.3 to 7.8 , whereas extractable $\mathrm{Ca}$ and $\mathrm{Mg}$ increased with increasing $\mathrm{pH}$. In contrast, patterns of tissue nutrient concentration of $\mathrm{B}$ in petunia, and $\mathrm{P}, \mathrm{Mn}$, and $\mathrm{Zn}$ in both species differed from those nutrient solubility patterns. This experiment therefore emphasized that the effect of substrate $\mathrm{pH}$ on tissue nutrient levels for plants grown in a soilless medium cannot be predicted based solely on nutrient solubility. Although $\mathrm{Fe}$ and $\mathrm{Cu}$ decreased in tissue with increasing $\mathrm{pH}$, in line with nutrient solubility in the medium (Peterson, 1981), foliar $\mathrm{Zn}$ increased with increasing substrate $\mathrm{pH}$. Mn levels also suggested a bimodal pattern with substrate $\mathrm{pH}$, and $\mathrm{Mn}$ levels were highest at $\mathrm{pH}$ 7. Trends in foliar $\mathrm{B}$ and $\mathrm{P}$ content differed between species (Tables 1 and 2), further illustrating the complexity of plant-rhizosphere interactions.

As hypothesized, increasing micronutrient level in the applied fertilizer did affect tissue levels, but only by increasing $\mathrm{Fe}$ and $\mathrm{Cu}$ in petunia, and $\mathrm{Fe}, \mathrm{Cu}$, and $\mathrm{B}$ in impatiens. $\mathrm{Mn}$ level actually decreased in petunia with the increasing micronutrient concentration, and was unaffected in impatiens. An optimum range in substrate $\mathrm{pH}$ for plant growth is based on the goal to allow "micronutrient cations to be soluble enough to satisfy plant needs without becoming so soluble as to be toxic" (Brady and Weil, 2000). Given that micronutrient levels in 
the media and tissue can increase as applied micronutrient fertilizerincreases, the optimum range in substrate $\mathrm{pH}$ for any crop may vary depending on the fertilizer strategy.

Uptake of Fe and Mn has often been shown to be mutually antagonistic (Warden and Reisenauer, 1991), and excess soluble Fe or Mn can suppress uptake of the less soluble of the two nutrients (Knezek and Greinert, 1971). The Fe to Mn ratio in water-soluble fertilizers is important in determining uptake and foliar concentration of the two nutrients, and the $\mathrm{Fe}$ : $\mathrm{Mn}$ ratio in the root medium is recommended to be between 1:1 and 2:1 (Hulme and Ferry, 1999). However, Reisenauer (1994) cautions that, "although the interaction of $\mathrm{Mn}$ and $\mathrm{Fe}$ appear to be a mutual antagonism, quantitatively the relationship is much more complex and its many aspects not well understood", and factors such as chelation, levels of other nutrients, and rhizosphere $\mathrm{pH}$ influence this interaction. The importance of Fe, $\mathrm{Mn}$, and their ratio on observed chlorosis in our experiment indicates the need to explore the potential to utilize highly soluble forms of Fe (e.g., Fe-EDDHA) in commercial greenhouse production, and varying the ratio between $\mathrm{Fe}$ and $\mathrm{Mn}$ in fertilizer, in order to reduce susceptibility to chlorosis at high substrate $\mathrm{pH}$.

\section{Literature Cited}

Adams, P., C.J. Graves, and G.W. Winsor. 1978. Some responses of lettuce, grown in beds of peat, to nitrogen, potassium, magnesium, and molybdenum. J. Hort. Sci. 53:275-281.

Albano, J.P. and W.B. Miller. 1998. Marigold cultivars vary in susceptibility to iron toxicity. HortScience 33:1180-1182.

Anderson, R.L. and L.A. Nelson. 1975. A family of models involving intersecting straight lines and concomitant experimental designs useful in evaluating response to fertilizer nutrients. Biometrics 31:303-318.

Argo, W.R. and J.A. Biernbaum. 1996. The effect of lime, irrigation-water source, and water-soluble fertilizer on the $\mathrm{pH}$ and macronutrient management of container root-media with impatiens. J. Amer. Soc. Hort. Sci. 121(3):442-452.

Argo, W.R. and P.R. Fisher. 2002. Understanding pH management for container-grown crops. Meister Publ., Willoughby, Ohio.

Bailey, D.A. and P.V. Nelson. 1998. Managing micronutrients in the greenhouse. N.C. State Univ. Coop. Ext. Hort. Info. Lflt. 553.

Bennett, J.P. 1945. Iron in leaves. Soil Sci. 60:91-105.

Biernbaum, J.A. and W.R. Argo. 1995. Effect of root-media $\mathrm{pH}$ on impatiens shoot micronutrient concentrations. HortSci. 30:858 (abstr.).

Biernbaum, J.A., W.H. Carlson, C.A. Shoemaker, and R. Heins. 1988. Low $\mathrm{pH}$ causes iron and manganese toxicity. Greenhouse Grower 6(3):92-93, 96-97.

Boxma, R. 1981. Effect of $\mathrm{pH}$ on the behavior of various iron chelates in sphagnum (moss) Peat. Comm. In Soil Sci. and Plant Anal., 12:755-63.

Brady, N.C. and R.R. Weil. 2000. Elements of the nature and properties of soils. Prentice Hall, Upper Saddle River, N.J.

Bunt, A.C. 1988. Media and mixes for containergrown Plants. Unwin Hyman, London.

Fisher, P.R., R. Wik, B.R. Smith, C.C. Pasian, M. Kmetz-González, and W.R. Argo. 2003. Correcting iron deficiency in Calibrachoa $\times h y b$ rida Cerv. grown at high $\mathrm{pH}$. HortTechnology 13(2):308-313.

Hulme, F. and S. Ferry. 1999. How to avoid micronutrient toxicity syndrome. GM Pro 19(12):25-31

Knezek, B.D. and H. Greinert. Influence of soil Fe and Mn-EDTA interactions upon the $\mathrm{Fe}$ and $\mathrm{Mn}$ nutrition of bean plants. Agron. J. 63:617-619.

Lindsay, W.L. 1979. Chemical equilibria in soils. $1^{\text {st }}$ ed. Blackburn Press, Caldwell, N.J.

Llorente, S., A. Leon, A. Torrecillas, and C. Alcaraz. 1976. Leaf iron fractions and their relation with iron chlorosis in citrus. Agrochimica 20:204-212.

Lucas, R.E. and J.F. Davis. 1961. Relationships between $\mathrm{pH}$ values of organic soils and availabilities of 12 plant nutrients. Soil Sci. 92:177-182.

Marschner, H. 1995. Mineral nutrition of higher plants. $2^{\text {nd }}$ ed. Academic Press, San Diego,
Calif.

Miller, G.W., J.C. Pushnik, and G.W. Welkie. 1984. Iron chlorosis, a world wide problem, the relation of chlorophyll biosynthesis to iron. J. Plant Nutr. 7:1-22.

Mills, H.A. and J.B. Jones. 1996. Plant analysis handbook II. MicroMacro Publ., Inc.

Nelson, P.V. 1998. Greenhouse operations and management. $5^{\text {th }}$ ed. Prentice Hall, Englewood Cliffs, N.J.

Norvell, W. A. 1991. Reactions of metal chelates in soils and nutrient solutions, p. 187-223. In: J.J. Mortvedt, F.R. Cox, L.M. Shuman, and R.M. Welch (eds.). Micronutrients in agriculture. $2^{\text {nd }}$ ed. Soil Sci. Soc. Amer., Madison, Wis.

Oserkowsky, J. 1933. Quantitative relation between chlorophyll and iron in green and chlorotic leaves. Plant Physiol. 8:449-468.

Peterson, J.C. 1981. Modify your pH perspective. Florists Rev. 169:34-36.

Reed, D. M. 1996. Micronutrient nutrition. Ch. 9. p. 171-195. In: D.M. Reed (ed.). Water, media, and nutrition for greenhouse crops. Ball Publ., Batavia, Ill.

Reisenauer, H.M. 1994. The interactions of manganese and iron, p.147-164. In: J.A. Manthey, D.E. Crowley, and D.G. Luster (eds.). Biochemistry of metal micronutrients in the rhizosphere. CRC Press, Boca Raton, Fla.

Smith, B.R., P.R. Fisher, and W.R. Argo. 2004. Growth and pigment content of container-grown impatiens and petunia in relation to root substrate $\mathrm{pH}$ and applied micronutrient concentration. HortScience 39(6): 1423-1427.

Vetanovetz, R.P. 1996. Tissue analysis and interpretation, p. 197-220. In: D.W. Reed (ed.). Water, media, and nutrition for greenhouse crops. Ball Publ., Batavia, Ill.

Warden, B.T. and H.M. Reisenauer. 1991. Manganese-iron interactions in the plant-soil system. J. Plant Nutr. 14:7-30.

Warncke, D.D. 1995. Recommended test procedures for greenhouse growth media. Ch. 11. In: Recommended soil testing procedures for the northeastern United States. 2nd ed. Univ. Del. Agr. Expt. Sta. Bul 493, Dec. 1995.

Wright, R.D. and A.X. Niemiera. 1987. Nutrition of container-grown woody nursery crops. Hort. Rev. 9:75-101. 